\title{
Analysis of the Effectiveness of the Relaxation Timeliness Policy for Financial Reporting Due to the Covid-19 Pandemic in Indonesia's Economic Resilience
}

\author{
Agrianti Komalasari ${ }^{1}$, Adrima Jusata Nicholas Tarigan ${ }^{2}$ \\ \{agriantiksa@gmail.com ${ }^{1}$, adrima.jusata13@gmail.com ${ }^{2}$ \} \\ Faculty of Economics and Business, University of Lampung, Indonesia ${ }^{1}$, Faculty of Economics and Business, \\ University of Lampung, Indonesia ${ }^{2}$
}

\begin{abstract}
This study reviews the financial reporting relaxation policies issued by the financial services authority for Capital Market Industry due to the Corona virus in Indonesia. This is Descriptive research the data is observed before and after the Covid-19 pandemic and later look at and assess how effective the policies issued are with the real conditions of the timeliness of financial reporting, and see how these policies affect one another. As result, it is found that the policy significantly effects the timeliness of financial reporting of the company listed in Stock exchange. Nonetheless what needs to be noted is that during a pandemic like this each sector has a different impact so that it cannot be equated with one another. As conclusion the policy of easing time limits can provide potential for rogue companies who try to carry out creative accounting practices during the extension.
\end{abstract}

Keywords: Timeliness, Covid-19, Financial Reporting, Stock Exchange, Policy

\section{INTRODUCTION}

The financial report is one of the important information instruments in business, the financial report is a portrait of the implementation of corporate responsibility to various parties with an interest in the financial statements of the company. Hence that financial reports are needed by interested parties to use these financial reports such as creditors, shareholders, and management. For this reason, financial statements will be very crucial in order to be reported accurately and on time to the users in order to make decisions related to the company. Timeliness is a strategic aspect for the company to gain a competitive advantage in supporting the success and sustainability of the company, as well as maintaining the company's good name and increasing public confidence in the quality of the information presented and the quality of the company.

Accounting theory has always recognized that the timeliness of financial statements is an important characteristic to judge their relevance [1]. Disclosure timeliness is of concern because a report's usefulness may be inversely related to the reporting delay. Although longer delays increase the likelihood that some of the information contained in annual earnings disclosures will be preempted by information from more timely sources, previous research investigating the relation between earnings-disclosure timeliness and the intensity of the associated market reaction has reported mixed results [2].

The timeliness of reporting from the company's financial statements can be interpreted as a good signal to assess the quality of company performance, as well as the credibility of the quality of financial reports and good accounting information. [3] stated that the value of the timeliness of financial reporting is an important determinant of the level of usefulness of financial statements. The value of the timeliness of financial reporting is an important determinant of the level of benefit of a financial report [4].

Some companies post their Financial Disclosure filings well after the due date, thereby gaining unfairly by acting on the Financial Disclosure information prior to public disclosure [5]. Research shows that companies whose audit reports meet the requirements (audit reports contain auditors' statements) and companies that have statements that are more significant than their equity capital are directly or indirectly owned by insiders (i.e. top management and directors) do not immediately release financial statements that are audited to the public after the public end of their financial year [6]. Also, there is no empirical evidence to support the cost theory, which postulates that firms are highly geared towards the market. In the Nigeria the regulations established can reduce the financial reporting position even though this is not enough to ensure the quality of the financial statements produced [7]. 
In Indonesia, the timeliness of submitting annual financial reports has been regulated by Law in 1995 . according to Law Number 8 of 1995 concerning the Capital Market defines the Principle of Disclosure as a general guideline which requires Companies and Public Companies or other parties to disclose all material information that may influence investors' decisions regarding the said Securities or the price of these Securities to the public immediately. Based on the Principle of Openness, the submission of reports and disclosure of information by Companies or Public Companies in a timely manner, both to the Financial Services Authority and to the public, is an important element that must be considered so that there are no gaps in information that could potentially harm investors. and has been updated by BAPEPAM in 1996 and 2012, namely the capital market regulations which state that all companies listed on the stock exchange securities must submit periodic financial reports to BAPEPAM starting from the end date of the financial year and announce the report to the public. If the company is late in submitting a report in accordance with the provisions stipulated in the law, it will be subject to quite heavy sanctions and fines. In 2020 a pandemic arose caused by the corona virus and spread in Indonesia, causing disruption of many public activities both at macro and micro levels, including the capital market and the instruments in it. Through a press release from the Financial Services Authority, it was stated that during the pandemic, companies were given facilities to be able to compile their financial reports in the midst of a pandemic without being overshadowed by late fines.

The policy issued by the financial services authority aims to protect the company so that the image and credibility of the company against lenders, financial analysts and regulators does not collapse and become bad due to the possibility of delays in financial reporting, the relaxation of financial reporting time issued by the OJK also raises questions about the urgency from this policy because in general the financial statements are predicted to have been completed in December of the previous financial year, namely 2019. Where it should not be significantly affected because the policy issued by the Government regarding large-scale social restrictions was in mid-March.

This study aims to review whether the delay in submitting the company's 2019 financial statements is one of the effects of the Covid-19 pandemic, and see if there are other possible arguments that cause delays in financial reporting, which underlies the issuance of this policy and the company reaction to the issuance of this policy. whether it will affect the company who are generally on time, and vice versa

\section{LITERATURE REVIEW}

\section{Signaling Theory}

Signaling theory assumes that there is information asymmetry between managers and investors or potential investors. Managers are seen as having information about the company that neither investors nor potential investors have. Signaling theory explains the reasons why companies present information to the public. This information can be in the form of financial reports, company policy information or other information that is voluntarily disclosed by company management.

Investor decisions are influenced by the quality of information disclosed by companies in the financial statements. The quality of this information aims to reduce the information asymmetry that arises when managers know more about the company's internal information and prospects in the future than the company's external parties. Information in the form of published reporting timeliness is expected to signal the condition and quality of a particular company. In the process of preparing and reporting financial statements, companies often carry out earnings management and use the services of high quality third parties, such as auditors. This effort is carried out in order to provide a signal to investors and potential investors to reduce the problem of information asymmetry, so that investors or potential investors believe that the company has high quality. Relevant signaling theory is used as a reference in this research because the signals and information circulating can influence the actions taken by investors.

\section{Timeliness}

To see the timeliness, usually a study looks at the delay in reporting (lag). There are three criteria for delay [4]: (1) preliminary lag: the interval of the number of days between the date of the financial statements until the receipt of the final preliminary report by the stock exchange; (2) auditor's report lag; interval number of days between the date of the financial statements until the date the auditor's report is signed (3) total lag: the interval of the number of days between the date of the financial statements until the date when the report is published by the stock exchange. [5] find that some United States companies post their Financial Disclosure filings well after the due date, thereby gaining unfairly by acting on the Financial Disclosure information prior to public disclosure. 
Delays in reporting financial statements can be an opportunity for misuse or recognition of company assets. Timely reporting serves to reduce the adverse effects of moral harm and adverse implications [8]. This is a voluntary decision related to corporate disclosure and, therefore, can be used to test disclosure decision theories. Other things being equal, it might be expected that all companies would disclose the information as quickly as possible to avoid adverse selection. News that is liked may be expected to be reported earlier than news that is not profitable. There may also be an agent compensation effect in news that is favorable more likely to be appreciated. suggests that the incentive to disclose information is a decreasing function of the potential cost of ownership inherent in disclosure and an increasing function of the likability of news in disclosure.

This study aims to review the policy of easing financial statements deadline issued by the Financial Services Authority to try to reduce the burden on companies in the midst of the effects of the Covid-19 pandemic, whether the Covid-19 pandemic is the cause of delays in financial reporting that occurred on the stock exchange. in this policy, the deadline for report submission is extended by two months from the expiration of the report submission obligation as referred to in the regulations in the Capital Market.

\section{METHODOLOGY AND ANALYSIS}

\section{Data and Method}

The data set for this study is based on secondary time-series data collected with respect to industry attributes for the period 2017-2019. The target population consists of companies listed on the Indonesia Stock Exchange. There is a total of 702 listed companies in Indonesian Stock Exchange and filtered according to the availability of data on the Indonesia Stock Exchange resulting of 644 companies available to be sampled excluding the delisting and recently listed company with no historic data available. This research using descriptive method as the way to explain the phenomenon happen in the pandemic, in addition to using the descriptive method, this research also uses analysis of the relationship between two variables before and after the implementation of the financial reporting easing policy.

\section{RESEARCH RESULTS AND DISCUSSION}

The rapid development of Covid-19, causing approximately 199 countries with populations to be infected with the corona virus, including Indonesia. Indonesia as one of the countries visited by Covid-19, the presence of these uninvited guests not only causes health problems, but also causes social impacts such as community panic, crisis of trust, and the most severe impact is a slowdown in national economic growth. Not one country wants it, but it is not the power to reject it in more than 110 countries in the world. Superpowers such as the United States, China, Italy, France, Spain and others have no power to refuse their presence and struggle to fight and stop the spread.

The economic slowdown as a result of the Covid-19 pandemic hit the macro and micro economies, not only in the informal and formal sectors. Even non-physical markets such as the capital market have been hit hard. It is recorded that mid-March is the worst week in the last one year when referring to the Composite Stock Price Index (IHSG). The pandemic brings its own horror to the stock market which is starting a new beginning in 2020, starting from the sharp drop in the index and the exit of foreign investors from the stock exchange. Policies have begun to be discussed and determined by the government so that the effects of the pandemic do not get worse, one of the topics discussed is the policy issued through the OJK press release, namely the easing of the deadline for submitting reports and the implementation of the General Meeting of Shareholders (GMS) for Capital Market Industry players as efforts to adapt to emergency conditions due to the Corona virus in Indonesia. This easing then raises questions about whether or not this policy is appropriate in helping capital market industry players.

\section{General Condition Before COVID-19 Pandemic}

COVID-19 are classified as non-natural disaster; accordingly, it can be alleged that covid-19 pandemic is an unplanned event / phenomenon, there are conditions where the company runs normally without being affected by the pandemic. In this study, the normal condition of the company was limited to two years before COVID-19, namely 2018 and 2019, so that the 2017 and 2018 financial year reporting schedule was used. 
Table 1 General Condition Before Pandemic

\begin{tabular}{lrrrr}
\hline & \multicolumn{2}{c}{2017} & \multicolumn{2}{c}{2018} \\
\hline On time & 371 & $57,6087 \%$ & 412 & $63,9752 \%$ \\
delayed & 293 & $42,3913 \%$ & 252 & $36,0248 \%$ \\
$\mathrm{~N}=664$ & 664 & $100 \%$ & 664 & $100 \%$ \\
\hline
\end{tabular}

Table Source: Authors Finding

If we look at historical data based on the table 1 from a total of 664 company companies in the past two years in a row, it turns out that there were 292 companies or $42.3913 \%$ from total company in 2017 and 252 companies or $36.0248 \%$ from total companies that were presumably late in submitting their company's annual financial statements to the stock exchange. Based on this, it can be said that under normal conditions with a growing economy of 5.07\% yoy (2017) 5.17\% yoy (2018) companies are still experience delays in reporting their audited financial statements to authority. At this point the researchers assume that in the stressful conditions of the COVID-19 pandemic, it is possible to cause companies to experience significant delays and quite severe.

For the 2019 financial statements that are scheduled to be reported in March 2020, and then finally experience easing for two months until May 2020.

Table 2 Comparison Table Between Before and After

\begin{tabular}{lcccc}
\hline & \multicolumn{4}{c}{$31^{\text {st }}$ May 2020 } \\
\hline on time & 110 & $17,0807 \%$ & 546 & $84,7826 \%$ \\
delayed & 554 & $82,9193 \%$ & 118 & $15,2174 \%$ \\
\hline
\end{tabular}

Table Source: Authors Finding

The data presented table 2 illustrates a few of the company's conditions during the Covid-19 pandemic. The data displayed in the table contains categories that are used as a comparison, namely before the regulation takes effect and after. The frequency presented describes the number of companies that report their financial statements on time or late by using the deadline before the new regulation takes effect (31 March 2020) and after the easing regulation comes into effect (31 May 2020).

Based on the data presented in the table, it can be determined that there are many companies that are still able to submit their financial reports on time, even though in quantity matter the numbers have decreased significantly from 2018 and even 2017. On paper the numbers presented are 110 companies for year of 2019, very far compared to 412 company for year of 2018. Consequently, there is no strong enough evidence to conclude that companies that are timely in reporting their financial reports are not affected by the Covid-19 pandemic. It is assumed that the increase in the number of companies that are late in reporting their financial reports is the effect of the Covid-19 pandemic that occurred in Indonesia, both directly and indirectly.

Still referring to the same data table, the section after the easing of financial statements in accordance with the policy of the financial services authority, the number of companies that was previously very low became very high, an increase that occurred up to eight times. Referring to this table alone, it can be concluded that this financial reporting policy is very influential in changing the dynamics that occur in the stock market, this can be seen from table 3 that statistically using the pair sample test before and after the regulation there is a significant difference.

Table 3 Paired Sample Test

Paired Samples Test

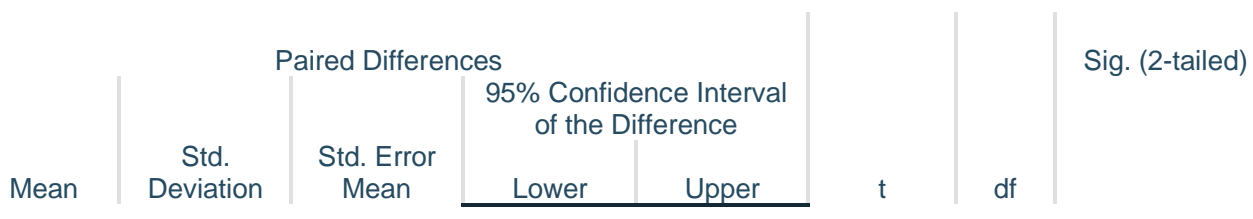




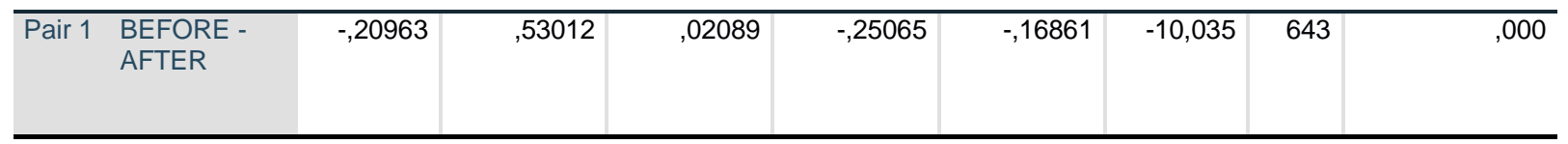

\section{Table Source: Authors Calculation using IBM SPSS 25}

From the existing data, it can be concluded that this regulation is effective in helping companies to report their financial statements. What is not discussed, however, is how this regulation could have such an effect.

The process of preparing, examining and reporting financial in general will take a long time, even in some studies, company size has a significant effect on audit delay and timeliness of financial statement reporting. [9][10][11]. There are many factors that can affect the timeliness of reporting financial statements, if examined more deeply before reporting. Financial statements are first audited by a public accountant or external auditor; before being submitted to the Financial Services Authority. The auditing process carried out by the auditor can run fast or long depending on the financial reports he is doing. Long auditing can lead to delays in submitting financial reports to the Financial Services Authority. Delay in the publication of financial reports can be an indication that there is a problem with the company's financial statements, so that it takes longer to complete the financial statements. Delays in information will cause negative reactions from capital market players and are indirectly interpreted by investors as a bad signal for the company.

The factors that cause the length of time for auditing to complete are not limited to internal factors, but also external factors. Internal factors are usually influenced by profitability, company age, profit and loss and solvency. Meanwhile, external factors are usually influenced by the quality of the public accounting firm (KAP) that audits the company's financial statements. A long-established public accounting firm that carries out many auditing processes requires a shorter time to complete the audit, because the KAP is considered to be able to carry out audits more efficiently and have a higher degree of time schedule flexibility to complete the audit appropriately [12].

The key to timeliness of financial report reporting lies in the process of preparing financial reports as well as auditing by external auditors or public accountants. During this pandemic, the audit process can be disrupted due to policies issued by the government to ensure mutual security and prevent the spread of Covid-19. In addition, at the beginning of 2020 the examination period or phase will run slower because each company and public accounting firm must prepare a Health protocol as an effort to reduce the spread of the Covid-19 virus.

Based on this, it can be said that it makes sense that this policy has been effective in reducing the side effects of the pandemic on companies affected by the Covid-19 pandemic. But what is not possible to discuss in depth from this study is the probability of companies engaging in creative accounting practices within the company by taking the loophole of loosening the two-month reporting period. For this reason, researchers also tried to look deeper into the existing timeliness data, then presented it in table form as presented in the table.

Table 4 Miscellaneous Data Findings

\begin{tabular}{ccccc}
\hline & on time & on time & & \\
& $31 / 3 / 2020$ & $31 / 5 / 2021$ & Always delayed & Being delayed \\
\hline $\mathrm{N}$ & 82 & 274 & 49 & 16 \\
$\%$ & $12,7329 \%$ & $42,5466 \%$ & $7,6087 \%$ & $2,4845 \%$ \\
\hline
\end{tabular}

Table Source: Authors Finding

Based on the table, there are $82(12.7329 \%)$ companies whose financial reporting did not experience any delays at all in the last three years if the deadline was March 31, 2020. If the latest regulation relaxed the deadline for reporting financial statements, the number of companies on time increased. to $274(42.5466 \%)$, there was an increase of $165(29.8137 \%)$ companies, which is more than a quarter of the total number of companies, then there are 49 (7.6087\%) of companies who are always late regardless of their conditions, meaning that these companies are experiencing delays not only due to the Covid-19 pandemic there are still other things that affect the issuer's late financial reporting. The findings that the researchers obtained in this study were $11(2.4845 \%)$ of companies who were originally late to report their financial statements, if seen based on the number it is not too significant, but the motives and reasons that may underlie this phenomenon can be an interesting topic for discussed in depth in other studies later. 


\section{CONCLUSION}

Using these results, it can be concluded that the government policy through the financial services authority to stretch/relaxed the deadline for financial reporting is significantly influential in helping companies to report their financial statements. In the midst of a pandemic condition that forces the public to carry out physical distancing and limit the space for movement, of course it will be difficult, including the auditing process, but what should be noted is that this policy of easing time limits can provide potential for rogue companies who try to carry out creative accounting practices during the extension. If you look at the issuance date of the policy, the number of companies should be late only half because it is assumed that during that period each issuer has been audited by an external auditor or a public accountant. Therefore, the role of the Financial Services Authority and the Indonesian Stock Exchange must also be active in monitoring each registered company to reduce misstatements and fraudulent acts of financial reports amid the Covid-19 pandemic.

\section{REFERENCES}

[1] J. Lawrence and H. Glover, "The Effect of Audit Firm Mergers on Audit Delay," J. Manag. Issues, 1998.

[2] R. K. Atiase, L. S. Bamber, and S. Tse, "Timeliness of financial reporting, the firm size effect, and stock price reactions to annual earnings announcements," Contemp. Account. Res., 1989, doi: 10.1111/j.19113846.1989.tb00722.x.

[3] D. Givoly and D. Palmon, "Timeliness of Annual Earnings Announcements: Some Empirical Evidence," Account. Rev., 1982.

[4] J. C. D. IV and A. J. McHugh, "The Timeliness of the Australian Annual Report," J. Account. Res., 1975, doi: $10.2307 / 2490361$.

[5] P. A. Griffin, D. H. Lont, and B. Segal, "Enforcement and disclosure under regulation fair disclosure: An empirical analysis," Account. Financ., 2011, doi: 10.1111/j.1467-629X.2011.00446.x.

[6] S. Owusu-Ansah and S. Leventis, "Timeliness of corporate annual financial reporting in Greece," Eur. Account. Rev., 2006, doi: 10.1080/09638180500252078.

[7] F. O. Iyoha, "Company Attributes and the Timeliness of Financial Reporting of Nigeria," Bus. Intell. J., 2012.

[8] W. R. Scott, Financial Accounting Theory. New Jersey: Prentice-Hall, Inc., 2015.

[9] L. Melati and A. I. Sulistyawati, "AUDIT DELAY PADA PERUSAHAAN PERTAMBANGAN : ANALISIS DAN FAKTOR-FAKTOR PENENTUNYA,” J. Akunt. Indones., 2016, doi: 10.30659/jai.5.1.3756.

[10] F. A. Amani and I. Waluyo, "PENGARUH UKURAN PERUSAHAAN, PROFITABILITAS, OPINI AUDIT, DAN UMUR PERUSAHAAN TERHADAP AUDIT DELAY (Studi Empiris pada Perusahaan Property dan Real Estate yang Terdaftar di Bursa Efek Indonesia pada Tahun 2012-2014)," Nominal, Barom. Ris. Akunt. dan Manaj., 2016, doi: 10.21831/nominal.v5i1.11482.

[11] E. Puspitasari Anggraeni Nurmala Sari, "PENGARUH KARAKTERISTIK PERUSAHAAN TERHADAP LAMANYA WAKTU PENYELESAIAN AUDIT (AUDIT DELAY) PADA PERUSAHAAN MANUFAKTUR YANG TERDAFTAR DI BURSA EFEK INDONESIA,” J. Akunt. Audit., 2012.

[12] G. Whittred and I. Zimmer, "Timeliness of Financial Reporting and Financial Distress," Accounting Review. 1984. 